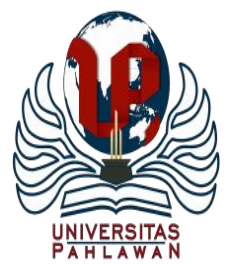

Edukatif : Jurnal Ilmu Pendidikan Volume 3 Nomor 5 Tahun 2021 Halm 3079 - 3089

EDUKATIF: JURNAL ILMU PENDIDIKAN

Research \& Learning in Education

https://edukatif.org/index.php/edukatif/index

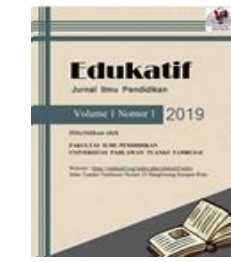

\title{
Kendala dalam Menumbuhkan Karakter Religius Anak Usia Sekolah Dasar selama Pandemi Covid 19
}

\author{
Unsa Sabrina $^{1 凶}$, Sekar Dwi Ardianti ${ }^{2}$, Diana Ermawati ${ }^{3}$ \\ Universitas Muria Kudus, Indonesia ${ }^{1,2,3}$ \\ E-mail : 201733044@ std.umk.ac.id ${ }^{1}$, sekar.dwi.arianti@ umk.ac.id² ${ }^{2} \underline{\text { diana.ermawati.@umk.ac.id }}^{3}$
}

\begin{abstract}
Abstrak
Tujuan dari penelitian ini untuk mengetahui kendala yang dihadapi orang tua dalam menumbuhkan karakter religius anak selama pandemi covid 19. Penelitian ini dilatarbelakangi oleh menurunnya karakter religius anak selama pandemi covid 19 di Desa Lau Kecamatan Dawe Kabupaten Kudus. Penelitian ini menggunakan jenis penelitian kualitatif deskriptif dengan subjek penelitian empat orang tua dan empat anak usia sekolah dasar. Teknik pengumpulan data dilakukan dengan cara wawancara, observasi, dan dokumentasi. Teknik analisis data menggunakan model Miles Huberman yaitu reduksi data, penyajian data, dan verifikasi atau kesimpulan. Uji keabsahan data dalam penelelitian ini menggunakan 2 model triangulasi yaitu triangulasi sumber dan triangulasi teknik. Hasil dari penelitian ini menunjukkan kendala yang dihadapi oleh orang tua antara lain: 1) Kesibukan orang tua yang bekerja, 2) Tidak adanya kesadaran dalam diri anak, 3) Kurangnya pengetahuan orang tua tentang mendidik anak, 4) Tidak adanya kerjasama yang baik dalam menumbuhkan karakter religius antara guru dan orang tua selama pandemi covid 19, dan 5) Pengaruh Lingkungan.
\end{abstract}

Kata Kunci: peran orang tua, karakter religius, pandemi covid 19.

\section{Abstract}

The purpose of this study was to find out the obstacles faced by parents in cultivating the religious character of their children during the covid 19 pandemic. This research was motivated by the decline in the religious character of children during the covid 19 pandemic in Lau Village, Dawe District, Kudus Regency. This study used descriptive qualitative research with four parents and four elementary school-aged children as research subjects. Data collection techniques were carried out by means of interviews, observation, and documentation. The data analysis technique uses the Miles, Huberman model, namely data reduction, data presentation, and verification of conclusions. The data validity test in this research uses 2 triangulation models, namely source triangulation and technical triangulation. The results of this study indicate the obstacles faced by parents include: 1) The busyness of working parents, 2) Lack of awareness in the child, 3) Lack of parental knowledge about educating children, 4) There is no good cooperation in cultivating religious character between teachers and parents during the covid 19 pandemic, dan 5) Environmental Influence.

Keywords: role of parents, religious character, covid 19 pandemic.

Copyright (c) 2021 Unsa Sabrina, Sekar Dwi Ardianti, Diana Ermawati

$\triangle$ Corresponding author

Email : 201733044@std.umk.ac.id

DOI : https://doi.org/10.31004/edukatif.v3i5.1233

ISSN 2656-8063 (Media Cetak)

ISSN 2656-8071 (Media Online) 
3080 Kendala dalam Menumbuhkan Karakter Religius Anak Usia Sekolah Dasar Selama Pandemi Covid 19 Unsa Sabrina, Sekar Dwi Ardianti, Diana Ermawati

DOI: https://doi.org/10.31004/edukatif.v3i5.1233

\section{PENDAHULUAN}

Karakter anak sangat berpengaruh terhadap nasib suatu bangsa di masa depan. Degradasi moral yang terjadi dapat dibenahi dengan adanya pendidikan karakter (Asyari et al., 2021). Anak yang berkarakter akan memiliki kecerdasan emosi yang baik. Ketika anak memiliki kecerdasan emosi yang baik maka anak mampu menghadapi segala macam tantangan sehingga mampu menyongsong masa depan dengan baik (Setiardi, 2017). Menumbuhkan karakter anak merupakan upaya seumur hidup yang melibatkan lingkungan keluarga, lingkungan sekolah/perguruan tinggi, dan lingkungan masyarakat yang harus berjalan terintegritas dan terpadu (Kurniawan, 2016). Karakter seseorang tidak dapat diubah, akan tetapi dapat dikuatkan atau dilemahkan, maka orang tua yang menjadi acuan pertama dalam menumbuhkan karakter anak dan perlu dibekali ilmu dalam mendidik anak. Menumbuhkan karakter anak dilakukan secara terus menerus sehingga menjadi suatu kebiasaan. Pembiasaan nilai-nilai karakter anak menekankan pada nilai-nilai kebaikan dan nilai yang dianggap buruk kemudian dibangun melalui pemahaman, pengahayatan, dan pengalaman secara langsung dalam kehidupan sehari-hari sehingga anak akan tahu, paham, kemudian melaksanakan nilai-nilai karakter dalam kehidupan sehari-hari (Setiardi, 2017). Menumbuhkan karakter anak tidak hanya tanggung jawab sekolah, akan tetapi orang tua juga memiliki tanggung jawab besar terhadap karakter anak.

Tujuan pendidikan karakter antara lain (1) Mengembangkan potensi afektif anak sebagai manusia dan warga negara yang memiliki karakter dan nilai-nilai budaya bangsa. (2) mengembangkan kebiasaan atau perilaku yang terpuji dan sejalan dengan karakter dan nilai-nilai budaya bangsa. (3) Menanamkan jiwa kepemimpinan dan tanggung jawab kepada anak. (4) Mengembangkan kemampuan anak yang mandiri, kreatif dan berwawasan kebangsaan. (5) Mengembangkan lingkungan yang jujur, penuh kreatifitas dan persahabatan, serta memiliki rasa kebangsaan yang tinggi (Abdusshomad, 2020). Sementara, fungsi utama pemdidikan karakter menurut Zubaedi (2011) diantranya (1) Fungsi Pembentukan dan Pengembangan Potensi yaitu membentuk dan mengembangkan potensi anak agar berperilaku baik, berhati baik, berpikiran baik sesuai dengan falsafah Pancasila. (2) Fungsi Perbaikan dan Penguatan yaitu memperbaiki dan memperkuat peran keluarga, masyarakat, satuan pendidikan, dan pemerintah berpartisipasi dan bertanggung jawab pengembangan dan pembangunan bangsa yang maju, sejahtera dan mandiri. (3) Fungsi Penyaring yaitu menyaring budaya bangsa lain yang tidak sesuai dengan karakter yang bermartabat.

Pendidikan karakter religius menjadi salah satu nilai dalam pendidikan karakter yang sangat diperlukan anak sebagai tolak ukur baik buruknya tingkah laku anak. Pendidikan karakter religius merupakan proses tranformasi nilai-niali agama yang menjadi kepribadian seseorang sehingga menjadi satu dalam perilaku seseorang (Alifah, 2020). Terdapat 18 nilai-nilai dalam pendidikan karakter. Menurut Azzet (2014) dari 18 nilai-nilai dalam pendidikan karakter, pendidikan karakter religius menjadi nilai yang sangat penting karena berkaitan dengan keyakinan seseorang terhadap kebenaran nilai agama yang di anutnya sehingga mampu menjadi motivasi yang kuat dalam membangun karakter. Karakter religius memiliki 3 dimensi yaitu hubungan individu dengan Tuhan, hubungan individu dengan individu serta hubungan individu dengan lingkungan (Kemendikbud, 2017). Menurut Istifany (2018) terdapat beberapa indikator karakter religius antara lain taat kepada Allah, Syukur, Ikhlas, Sabar, Tawakal, Qanaah, Percaya diri, rasional, kritis, kreatif, inovatif, mandiri, bertanggung jawab, cinta ilmu, hidup sehat, berhati-hati, rela berkorban, pemberani, dapat dipercaya, jujur, menepati janji, adil, rendah hati, malu berbuat salah, pemaaf, berhati lembut, setia, bekerja keras, tekun, ulet, gigih, teliti, berpikir positif, disiplin, antisipatif, visioner, bersahaja, bersemangat, dinamis, hemat, menghargai waktu, produktif, ramah, terbuka, sportif, tabah, tertib, taat aturan, toleran, peduli.

Keluarga menjadi lingkungan yang sangat strategis untuk penyadaran, penanaman dan pengembangan karakter anak karena adanya perasaan yang terpadu antara sifat mengayomi pada orang tua dan sifat diayomi pada anak (Setiardi, 2017). Orang tua memegang peranan penting dalam mengembangkan potensi anak karena orang tua yang menjadi pendidik pertama dan utama di lingkungan keluarga (Widianto, 2015). Peran orang 
3081 Kendala dalam Menumbuhkan Karakter Religius Anak Usia Sekolah Dasar Selama Pandemi Covid 19 Unsa Sabrina, Sekar Dwi Ardianti, Diana Ermawati

DOI: https://doi.org/10.31004/edukatif.v3i5.1233

tua tidak hanya memenuhi kebutuhan makan, pakaian, memberikan perlindungan, akan tetapi orang tua berperan penting dalam menentukan masa depan anak dalam hal pendidikan (Fatmala et al., 2021). Intensitas komunikasi dan kedekatan antara orang tua dan anak dapat menjadi sarana yang tepat dan efektif dalam mendidik anak agar memiliki karakter yang baik dan melekat pada anak. Namun, dalam mendidik dan memberikan pemahaman kepada anak, orang tua harus memiliki kepribadian yang unggul disamping memiliki pengetahuan yang cukup, baik dari pendidikan formal, teknologi, informasi dan yang paling utama mengenai pemahaman agama (Mahmudin \& Muhid, 2020). Peran orang tua dalam menumbuhkan karakter anak menurut Prabowo, dkk (2020) antara lain sebagai pendidik, sebagai fasilitator, sebagai pengawas dan pendamping, sebagai motivator, dan sebagai contoh figur yang baik.

Menumbuhkan karakter religius memerlukan kerjasama yang baik antara guru dan orang tua agar mendapat hasil yang maksimal karena pada anak usia SD, guru dijadikan sebagai sosok yang diidolakan. Sehingga segala sesauatu yang berasal dari guru baik penampilan, gaya bicara, bahasa yang digunakan akan mudah ditiru oleh anak. Namun, pada masa pandemi covid 19 seperti ini, peran guru dalam menumbuhkan karakter religius anak tidak dapat dilaksanakan dengan baik. Covid 19 merupakan penyakit menular yang disebabkan oleh Severe Acute Respiratory Syndrome Coronavirus 2 (SARS-CoV 2). Virus ini menyerang bagian pernafasan dan dapat menyebabkan kematian serta mudah menular dengan gejala seperti flu, mulai demam, batuk, pilek atau gangguan hidung. Untuk itu, sejak 16 Maret 2020, pemerintah mengubah pembelajaran tatap muka dengan pembelajaran secara daring untuk menghindari adanya kerumunan yang berpotensi untuk menularkan virus. Pembelajaran daring merupakan sebuah interaksi antar pengajar dan pembelajar atau antar siswa dengan guru melalui jaringan komputer, handphone atau alat komunikasi yang lain (Trisnadewi \& Muliani, 2020), Adanya kebijakan pembelajaran daring tersebut, orang tua memiliki tanggung jawab penuh dalam mendidik anak karena setiap hari anak melaksanakan kegiatan-kegiatan seharihari di rumah.Orang tua yang harus memantau kegiatan anak sehari-hari, mendampingi belajar, serta tetap menerapkan pendidikan karakter kepada anak agar pembelajaran yang dilakukan secara daring dapat terlaksana tanpa mengurangi tujuan dalam pembelajaran. Namun, proses pembelajaran daring terutama dalam pendidikan karakter yang sistematis bagi sebagian kelauraga sangat sulit terutama bagi orang tua yang sibuk dengan pekerjaan di luar rumah. Sehingga, proses pertumbuhan karakter anak kurang maksimal.

Pada penelitian sebelumnya, telah dilakukan penelitian menganai analisis karakter religius siswa di SD N 03 Suruh Tasikmadu Karanganyar Tahun Ajaran 2016/2017 oleh Roesdiana (2017) yang membahas tentang pembentukan karakter religius serta kendala yang dihadapi oleh guru dalam menumbuhkan karakter religius siswa. Adapun penelitian terdahulu mengenai analisis karakter religius siswa dalam belajar dari rumah pada masa pandemi covid 19 oleh Roziqin (2021) yang fokus membahas tentang proses belajar mengajar selama pandemi covid 19 serta pengaruhnya terhadap karakter religius siswa. Penelitian mengenai karakter religius juga dilakukan oleh Aisya (2019) yang fokus membahas tentang upaya guru dalam menumbuhkan karakter religius peserta didik di SDN Kompleks IKIP 1 Makassar. Namun, belum ada penelitian mengenai kendalakendala yang dihadapi oleh orang tua dalam menumbuhkan karakter religius anak selama pandemi covid 19 . Keterbaruan dalam penelitian ini terletak pada kendala-kendala yang dihadapi oleh orang tua dalam menumbuhkan karakter religius anak dilihat dari upaya-upaya yang dilakukan oleh orang tua dalam menumbuhkan karakter religius selama pandemi covid 19. Sehingga, tujuan dari penelitian ini untuk mengetahui kendala-kendala dalam menumbuhkan karakter religius anak usia SD selama pandemi covid 19 di Desa Lau Kecamatan Dawe Kabupaten Kudus.

Penelitian ini dilatar belakangi oleh temuan dilapangan mengenai menurunnya karakter religius anak selama pandemi covid 19. Terlihat dari hasil observasi awal terhadap 4 orang anak beserta orang tua di desa Lau pada tanggal 28 -29 Maret 2021 karakter religius anak rendah, terlebih pada saat pandemi covid 19. Hal ini terjadi karena kurangnya kontrol orang tua yang bekerja setiap hari. Berbeda ketika di sekolah, setiap hari kegiatan siswa dipantau dan diarahkan oleh guru. Menurunnya karakter religius juga disebabkan kurangnya 
3082 Kendala dalam Menumbuhkan Karakter Religius Anak Usia Sekolah Dasar Selama Pandemi Covid 19 Unsa Sabrina, Sekar Dwi Ardianti, Diana Ermawati

DOI: https://doi.org/10.31004/edukatif.v3i5.1233

kesadaran orang tua menganai pentingnya pendidikan karakter utamanya pendidikan karakter religius bagi anak. Para orang tua masih beranggapan bahwa anak-anak mereka masih kecil sehingga penumbuhan katakter religius belum diperlukan terutama bagi orang tua yang memiliki pendidikan rendah. Padahal menumbuhkan karakter bukanlah proses yang singkat, perlu proses yang intens dan berkesinambungan agar anak terbiasa dengan kegiatan tersebut dan menerapkannya dalam kehidupan sehari-hari serta dapat melekat samapi dewasa. Berdasarkan teori mengenai karakter religius, menurut Utami (2014) salah satu aspek dalam karakter religius adalah aspek sikap dan perilaku menjalankan ajaran agama yang dianutnya seperti sholat, puasa, sedekah, mempunyai jadwal khsus untuk mengaji. Namun, pada penelitian yang peneliti lakukan, anak belum melaksanakan karakter religius dengan baik, terlihat terdapat anak yang belum melaksanakan sholat 5 waktu,belum melaksanakan puasa, sholat 5 wakt dan lain-lain. Hal ini dapat disimpulkan bahwa ada kesenjangan mengenai kegiatan-kegiatan religius yang dilakukan oleh anak dibandingkan dengan teori yang sudah ada.

Permasalahan-permasalahan yang terjadi diatas peneliti tertarik untuk meneliti lebih lanjut mengenai kendala dalam menumbuhkan karakter religius anak usia sekolah dasar di desa Lau Kecamatan Dawe Kabupaten Kudus. Tujuan dari penelitian ini untuk mengetahui kendala-kendala yang dihadapi dalam menumbuhkan karakter religius selama pandemi covid 19.

\section{METODE PENELITIAN}

Penelitian ini dilaksanakan di Desa Lau Kecamatan Dawe Kabupatem Kudus. Tepatnya $12 \mathrm{~km}$ dari arah kota. Penelitian dilakukan selama satu bulan di bulan Mei. Penelitian ini menggunakan pendekatan kualitatif dengan jenis penelitian deskriptif. Penelitian kualitatif merupakan penelitian yang bertujuan memahami fenomena yang dialami oleh subyek penelitian seperti perilaku, persepsi, fenomena, motivasi, tindakan dan sebagainya (Shidiq \& Choiri, 2019). Sedangkan deskriptif merupakan jenis penelitian yang memanfaatkan data-data yang ada untuk memecahkan masalah. Jenis penelitian deskriptif kualitatif yang digunakan pada penelitian ini dimaksudkan untuk memperoleh informasi mengenai orang tua dan anak di Desa Lau Kecamaatn Dawe Kabupaten Kudus.

Subjek dalam penelitian ini adalah 4 anak usia SD yaitu FRP, INH, NAL, dan KI beserta 4 orang tua yaitu Ibu WP, Ibu SA, Ibu DS, dan Ibu SN. Teknik pengambilan subyek penelitian adalah purposive sampling. Data yang dikumpulkan oleh peneliti berasal dari 2 sumber yaitu data primer dan data sekunder. Data primer merupakan data yang diambil dari informan yang dianggap mampu mempresentasikan atau memaparkan masalah yang dijadikan obyek dalam penelitian. Sumber data primer dalam penelitian ini diperoleh dari orang tua dan siswa. Orang tua yang memberikan informasi deskriptif mengenai kendala dalam menumbuhkan karakter religius selama pandemi covid 19 dan anak yang memberikan informasi deskriptif mengenai kegiatan-kegiatan religius yang dilakukan selama pandemi covid 19. Data sekunder merupakan informasi yang berasal dari buku, dokumen, internet, maupun media cetak (Wekke, 2019:14).

Tabel 1. Sumber Data

\begin{tabular}{llllll}
\hline No & Nama Anak & Kelas & $\begin{array}{c}\text { Nama Orang } \\
\text { Tua }\end{array}$ & \multicolumn{1}{c}{ Pekerjaan } & Pendidikan \\
\hline 1 & FRP & 4 & $\begin{array}{l}\text { Bapak : S } \\
\text { Ibu : WP }\end{array}$ & $\begin{array}{l}\text { Bapak : Polisi } \\
\text { Ibu : Guru }\end{array}$ & $\begin{array}{l}\text { Bapak : S1 } \\
\text { Ibu : S1 }\end{array}$ \\
\hline 2 & KI & 4 & $\begin{array}{l}\text { Bapak : NE } \\
\text { Ibu : DS }\end{array}$ & $\begin{array}{l}\text { Bapak : Sopir } \\
\text { Truck } \\
\text { Ibu : Buruh }\end{array}$ & $\begin{array}{l}\text { Bapak : SMP } \\
\text { Ibu : SMA }\end{array}$ \\
\hline
\end{tabular}


3083 Kendala dalam Menumbuhkan Karakter Religius Anak Usia Sekolah Dasar Selama Pandemi Covid 19 Unsa Sabrina, Sekar Dwi Ardianti, Diana Ermawati

DOI: https://doi.org/10.31004/edukatif.v3i5.1233

\begin{tabular}{llllll}
\hline 3 & INH & 5 & $\begin{array}{l}\text { Bapak : AM } \\
\text { Ibu : SA }\end{array}$ & $\begin{array}{l}\text { Bapak : } \\
\text { Wiraswasta } \\
\text { Ibu : Ibu Rumah } \\
\text { Tangga }\end{array}$ & $\begin{array}{l}\text { Bapak : SMP } \\
\text { Ibu : SMA }\end{array}$ \\
\hline 4 & NAL & 5 & $\begin{array}{l}\text { Bapak : MT } \\
\text { Ibu : SN }\end{array}$ & $\begin{array}{l}\text { Bapak : Buruh } \\
\text { Ibu : Buruh }\end{array}$ & $\begin{array}{l}\text { Bapak : SD } \\
\text { Ibu : SMP }\end{array}$ \\
\hline
\end{tabular}

Teknik pengumpulan data yang digunakan dalam penelitian antara lain observasi yang dilakukan kepada anak untuk mengetahui kegiatan religius yang dilakukan anak selama pandemi covid 19. Selain observasi juga melakukan wawancara kepada anak dan orang tua serta melakukan dokumentasi kegiatan. Data yang terkumpul kemudian dianalisis menggunakan teori lapangan model Miles and Huberman yaitu peneliti melakukan reduksi data, menyajikan data kemudian membuat kesimpulan yang berisi jawaban dari rumusan masalah yang dirumuskan sejak awal.

Teknik keabsahan data dalam penelitian ini menggunakan triangulasi sumber dan triangulasi teknik. Triangulasi sumber merupakan menguji kredibilitas dengan mengecek beberapa sumber antara lain orang tua, siswa dan data sekunder berupa artikel-artikel yang relevaan kemudian dideskripsikan, dikategorisasikan, dan dianalisis sehingga menjadi suatu kesimpulan. Sedangkan triangulasi teknik merupakan mengecek data dari sumber yang sama namun dengan teknik yang berbeda yaitu observasi dan wawancara. Pada penelitian ini, triangulasi teknik dilakukan kepada anak.

\section{HASIL DAN PEMBAHASAN PENELITIAN}

Penelitian ini dilaksanakan di Desa Lau Kecamatan Kabupaten Kudus. Berdasarkan hasil penelitian, peneliti menemukan beberpa kendala yang dihadapi orang tua dalam menumbuhkan karakter religius anak di Desa Lau Kecamatan Dawe Kabupaten Kudus yang menyebabkan menurunnya karakter religius anak selama pandemi covid 19.

Sejak bulan Maret 2020, pandemi covid 19 belum juga berakhir. Pandemi covid 19 memberikan dampak yang besar dalam bidang pendidikan salah satunya dengan diberlakukannya kebijakan pembelajaran daring untuk menghindari adanya kerumunan dan menekan penularan covid 19. Pada masa pandemi covid 19, peran keluarga sangatlah besar karena berubahnya sistem pembelajaran dari tatap muka menjadi tatap maya (Rangga et al., 2021). Sistem pembelajaran daring ini dilakukan dengan memanfaatkan teknologi komunikasi melalui rumah masing-masing untuk menciptakan sebuah pembelajaran yang mempunyai kualitas sama dengan pembelajaran yang dilakukan secara langsung di sekolah. Keluarga khususnya orang tua selama pandemi covid 19 harus memberikan perhatian dan pengawasan kepada anak, karena banyak anak yang menghabiskan waktu sehari-hari hanya dengan bermain dan mengabaikan proses pembelajaran daring (Rositania \& Ardianti, 2021). Keberhasilan pendidikan pada masa pandemi covid 19 ditentukan oleh beberapa hal diantaranya kesiapan sekolah, kesiapan guru dan kesiapan orang tua (Yunitasari \& Hanifah, 2020). Namun, dalam prosesnya pembelajaran daring memiliki banyak kendala.Terdapat beberapa kegiatan pendidikan yang tidak biasa dilakukan secara maksimal selama pembelajaran daring, diantaranya proses dalam menumbuhkan karakter anak, utamanya karakter religius.

Pendidikan karakter merupakan pendidikan budi pekerti yang melibatkan aspek pengetahuan, aspek perasaan, dan aspek tindakan (Azzet, 2014). Pendidikan karakter diharapkan menjadi solusi dari degradasi moral remaja bahkan anak dan mempu memberi dampak yang baik terhadap kemajuan kehidupan masyarakat (Setiawan, 2021). Pendidikan karakter menjadi hal yang sangat penting bagi anak karena karakter pada seorang anak di masa sekarang akan berpengaruh pada kebiasaan yang dilakukan di masa depan. Salah satu nilai-nilai dalam pendidikan karakter yang sangat berpengaruh terhadap kepribadian anak di masa depan adalah karakter religius. Namun, karakter religius dalam pembelajaran daring ini tidak dapat terlaksana 
3084 Kendala dalam Menumbuhkan Karakter Religius Anak Usia Sekolah Dasar Selama Pandemi Covid 19 Unsa Sabrina, Sekar Dwi Ardianti, Diana Ermawati

DOI: https://doi.org/10.31004/edukatif.v3i5.1233

dengan baik. Guru tidak dapat memantau secara langsung mengenai karakter religius anak. Berbeda ketika di sekolah, yang sudah memiliki program khusus dalam menumbuhkan karakter religius. Menumbuhkan karakter religius anak bukanlah proses yang instan. Diperlukan kerjasama yang baik antara orang tua, guru dan lingkungan sekitar untuk mendukung keberhasilan pendidikan karakter religious.

Karakter seorang anak dipengaruhi oleh faktor bawaan, tetapi presentasinya sangat kecil karena pertumbuhan moral akan tumbuh dengan baik jika berada pada lingkungan moral yang baik begitupula pertumbuhan moral anak buruk jika berada pada lingkungan yang buruk (Yogapurindina, 2020). Berdasarkan hasil observasi kepada 4 anak yaitu FRP, INH, KI dan NAL mengenai pendidikan karakter religius selama pandemi covid 19 menunjukkan hanya FRP yang masih menjalankan kegiatan-kegiatan religius dengan baik. sementara INH, KI dan NAL selama pandemi covid 19, kegiatan-kegiatan yang bernilai religius mengalami penurunan. Irhamna (2019) menyebutkan kendala yang dihadapi dalam menumbuhkan karakter antara orang tua yang sibuk bekerja, kurangnya pengetahuan mendidik anak, pergaulan anak, serta kurangnya kesadaran anak.

Berdasarkan hasil observasi dan wawancara dengan informan, kendala dalam menumbuhkan karakter religius anak antara lain.

\section{Kurangnya Pengetahuan Orang Tua}

Kurangnya pengetahuan orang tua menjadi salah satu kendala dalam menumbuhan karakter, utamanya karakter religius anak. Prabowo dkk (2021) menyebutkan yang menjadi faktor penghambat karakter religius adalah kurangnya pengetahuan orang tua tentang pentingnya pendidikan karakter religius. Salah satu informan, NAL siswi kelas 5 SD memiliki karakter religius yang rendah. Hal ini terlihat dari hasil wawancara dengan NAL sebagai berikut.

"Saat dirumah saya tetap melaksanakan sholat tapi masih bolong, puasa setengah hari kemudian saya mengikuti TPQ"

"Ibu saya jarang bertanya atau menyuruh saya melaksanakan kegiatan-kegiatan yang berkaitan dengan karakter religius"

Kemudian peneliti melakukan wawancara dengan Ibu SN, seorang buruh, pendidikan terakhir SMP, Ibu dari NAL.

"Saya tidak punya upaya khusus dalam menumbuhkan karakter religius anak"

"NAL sholatnya belum 5 waktu. Puasanya masih setengah hari menurut saya wajar karena memang masih kecil"

Hasil wawancara dengan NAL menunjukkan bahwa NAL belum melaksanakan kegiatan-kegiatan yang berkaitan dengan karakter religius seperti belum melaksanakan sholat 5 waktu, belum berpuasa, dan sebagainya. Pernyataan NAL tersebut dibenarkan oleh Ibu SN bahwa anaknya belum melaksanakan karakter religius dengan baik karena menurutnya sang anak masih kecil sehingga belum berkewajiban dalam melaksanakan kegiatan-kegiatan religius. Adapun hasil observasi dan wawancara yang peneliti lakukan kepada KI siswa kelas 5 SD yang mengalami penurunan dalam melaksanakan kegiatan-kegiatan yang berkaitan dengan karakter religius. Adapun hasil wawancara dengan KI sebagai berikut.

"Kegiatan-kegiatan yang saya lakukan di rumah hanya sholat tapi tidak 5 waktu, biasanya yang bolong sholat dzuhur dan subuh. Selain sholat, saya juga masih berangkat untuk TPQ, puasa ramadhan setengah hari, dan mengikuti tarawih"

"Saya selalu dinasehati agar melaksanakan kegiatan-kegiatan yang berkaitan dengan karakter religius"

Peneliti juga melakukan wawancara kepada Ibu DS, Ibu dari KI yang bekerja sebagai buruh dan lulusan SMA.

"KI sholatnya masih bolong-bolong mbak. Apalagi kalau subuh. Saya kalau mau bangunin kasihan"

“ Upaya yang saya lakukan biasanya saya nasehati biar tetap melaksanakan sholat dan kegiatankegiatan religius lain seperti puasa" 
3085 Kendala dalam Menumbuhkan Karakter Religius Anak Usia Sekolah Dasar Selama Pandemi Covid 19 Unsa Sabrina, Sekar Dwi Ardianti, Diana Ermawati

DOI: https://doi.org/10.31004/edukatif.v3i5.1233

Hasil penelitian dengan dengan Ibu SN dan Ibu DS, hampir sama. Ibu DS merasa kasihan jika harus membangunkan anaknya untuk sholat, sementara Ibu SN merasa anaknya masih kecil sehingga belum berkewajiban melaksanaan sholat. Salah satu kegiatan yang berkaitan dengan karakter religius yang hukumnya wajib sebagai pondasi dalam beragama adalah sholat. Sejak anak berusia 7 tahun, seharusnya sudah dibiasakan untuk melaksanakan sholat, bahkan pada saat anak sudah berusia 10 tahun, maka anak boleh dihukum dengan pukulan (Jannah \& Suryadilaga, 2020). Pendidikan karakter religius harus ditanamkan pada anak sejak anak masih kecil sehingga anak akan terbiasa melaksanakan kegiatan-kegiatan tersebut hingga dewasa.Selain itu, menurut Cagyaningrum (2017), masa anak-anak adalah masa keemasan karena anak memiliki banyak potensi yang bisa dikembangkan dan waktu yang tepat untuk menanamkan nilai-nilai karakter agar menjadi kepribadian yang baik.

Berbeda dengan Ibu SN dan Ibu DS, Hasil penelitian dengan Ibu WP yang merupakan seorang guru dengan pendidikan terakhir S1, Ibu dari FRP saat diwawancarai sebagai berikut. (06 Mei 2021).

"Proses menumbuhkan karakter di sekolah anak saya alhamdulillah sudah baik. Bahkan anak saya mulai terbiasa melakukan sholat tanpa disuruh. Hal ini karena anak sudah mulai terbiasa sejak TK mulai sholat. Puasa satu hari full dan sampai saat ini belum pernah bolong".

"Upaya yang pertama kali saya lakukan agar anak melaksanakan sholat, saya kasih tau tentang pentingnya sholat,puasa, mengaji, sedekah dan kegiatan-kegiatan religius lain. Setelah itu, saya memberikan contoh langsung kepada anak. Saya memberinya reward kayak sekarang ketika dia mau berpuasa sehari full selama satu bulan".

Pernyataan Ibu WP sejalan dengan hasil observasi dan wawancara kepada FRP siswa kelas 5 SD yang memiliki karakter religius yang baik. Berdasarkan FRP tetap melaksanakan kegiatan-kegiatan religius selama pandemi covid 19 seperti mengaji, sholat 5 waktu, puasa, mengaji dan bersedekah. Hal tersebut juga sejalan dengan hasil wawancara kepada FRP sebagai berikut.

"Kegiatan masih saya lakukan seperti sholat, puasa, menghafal surat-surat pendek kalau ada tugas dari bu guru, kemudian beramal jumat diganti dengan infaq ketika sholat jum'at, dan mengikuti TPQ"

"Biasanya saya dinasehati, diajak sholat bareng sama mama, terus dikasih hadiah"

Berdasarkan upaya-upaya yang dilakukan oleh orang tua menunjukkan bahwa pengetahuan orang tua menentukan karakter religius pada anak. Orang tua yang pendidikannya S1 memiliki upaya yang berbeda dengan orang tua yang pendidikannya hanya sampai SMA, SMP ataupun SD. Hal ini sejalan dengan

\section{Belum Adanya Kesadaran dalam Diri Anak}

Irhamna (2016) menyebutkan salah satu kendala dalam menumbuhkan karakter religius adalah belum adanya kesadaran dalam diri anak mengenai pentingnya melaksanakan kegiatan-kegiatan religius. Hasil wawancara yang relevan kepada informan anak sebagai berikut.

"Kalau tidak berpuasa, saya akan dimarahi Ibu dan dilaporkan kepada Ibu Guru" (KI, 06 Mei 2021)

"Karena kalau tidak sholat, ibu saya akan marah" (INH, 05 Mei 2021)

"Saya berangkat TPQ setiap hari, kalau tidak berangkat saya akan dimarahi ibu saya tidak dikasih uang jajan" (NAL, 07 Mei 2021).

Berdasarkan hasil wawancara dengan ketiga informan tersebut menunjukkan belum adanya kesadaran dalam diri anak mengenai pentingnya melaksanakan kegiatan-kegiatan yang berkaitan dengan karakter religius. Hal tersebut sejalan dengan penelitian yang dilakukan oleh Utami (2014) bahwa kurangnya kesadaran dalam diri anak dapat menghambat proses penumbuhan karakter religius, meskipun orang tua ataupun guru memberikan pembiasaan yang baik ataupun teladan kepada anak. Menurut Al-lum (2013), kesadaran dalam diri merupakan "the mother of change" artinya menjadi induk perubahan yang menjadi pembentuk sebuah karakter. Sehingga jika kesadaran dalam diri anak menjadi salah satu kendala dalam menumbuhkan karakter religius. 
3086 Kendala dalam Menumbuhkan Karakter Religius Anak Usia Sekolah Dasar Selama Pandemi Covid 19 Unsa Sabrina, Sekar Dwi Ardianti, Diana Ermawati

DOI: https://doi.org/10.31004/edukatif.v3i5.1233

\section{Kesibukan Orang Tua}

Selama pandemi covid 19, pembelajaran dilakukan secara daring dari rumah masing-masing. Namun, orang tua tidak dapat mengontrol secara langsung karena harus bekerja. Hasil penelitian dari Ibu DS, Ibu dari KI yang bekerja sebagai buruh dari pagi hinga menjelang sore hari menyatakan bahwa setiap hari tidak dapat mengontrol kegiatan anak dengan baik karena harus bekerja. Hal tersebut juga sejalan dengan pernyataan KI.

"Saya setiap hari bekerja, sedangkan bapaknya seminggu sekali baru pulang, kalau pagi hanya bersama dengan kakaknya dirumah yang hanya beda 3 tahun. Sehingga kegiatan anak tidak ada yang mengontrol. Saya hanya berpesan agar mengerjakan tugas-tugasnya". (Ibu DS, 06 Mei 2021).

"Saat pandemi covid 19, setiap pagi saya dirumah bersama kakak saya karena Ibu dan Ayah saya bekerja. Ibu saya pulang sekitar pukul 14.00 WIB. Sedangkan Ayah saya pulang 2 minggu sekali”. (KI, 12 Mei 2021).

Hal yang sama juga diutarakan oleh Ibu SN Ibu dari NAL yang mengatakan setiap hari bekerja sehingga tidak dapat mendampingi kegiatan-kegiatan anak. Ibu SN juga mengatakan bahwa ketika bekerja, sang anak dititipkan kepada neneknya di rumah. Hal yang sama juga diungkapkan oleh NAL.

"Saya tidak bisa mengawasi dan mendampingi selama 24 jam. Yang bisa mengawasinya dirumah selama 24 jam hanya neneknya, jadi saya berpesan juga kepada neneknya untuk memberi tahunya dan mengingatkan untuk belajar dan melaksanakan kewajiban-kewajiban lainnya" (Ibu SN, 07 Mei 2021)

"Ibu saya bekerja setiap hari saya di rumah hanya bersama nenek saya" (NAL, 13 Mei 2021)

Hasil penelitian tersebut menunjukkan bahwa orang tua tidak dapat mengontrol langsung kegiatan anak selama pandemi covid 19. Menurut Irhamna (2019) salah satu kendala yang dihadapi dalam menumbuhkan karakter antara orang tua yang sibuk bekerja sehinga tidak ada yang mengontrol kegiatan anak dengan baik. Hal tersebut sejalan dengan Muhsin (2017) yang mengatakan kendala dalam menumbuhkan karakter pada anak adalah kurangnya waktu untuk anak karena pekerjaan yang mengakibatkan intensitas perjumpaan dengan anak berkurang sehingga tidak karakter religius anak tidak dapat tumbuh dengan baik.

\section{Tidak adanya kerjasama guru dan orang tua selama Pandemi Covid 19}

Selama pandemi covid 19 guru tidak dapat memberikan contoh langsung kepada anak, sehingga Hal tersebut sesuai dengan hasil penelitian yang dilakukan oleh peneliti kepada INH yang menyebutkan bahwa selama pembelajaran dilakukan secara daring, guru hanya menyampaikan materi atau memberi tugas yang berkaitan dengan mata pelajaran tertentu tanpa mengupayakan anak untuk belajar mengenai pendidikan karakter. Pernyataan tersebut juga dikuatkan oleh Ibu SA, Ibu dari INH yang mengatakan selama pembelajaran dilakukan secara daring, guru tidak pernah mengingatkan atau menyuruh anak melakukan kegiatan-kegiatan yang berkaitan dengan karakter religius.

“ Selama pembelajaran daring, guru jarang menanyakan kegaiatn-kegiatan yang berkaitan dengan karakter religius. Guru hanya memberikan tugas atau memberi penjelasan mengenai materi pembelajaran saja."

Menumbuhkan karakter tidak dapat terwujud dengan sempurna tanpa pembiasaan di setiap aspek kehidupan anak (Rohman et al., 2021). Selama pandemi covid 19, guru hanya mengupayakan penyampaian materi pembelajaran kepada anak. Guru tidak membentuk kerjasama dengan orang tua, sehingga program religius yang telah di tetapkan di sekolah tidak dilaksanakan di rumah. Selama pembelajaran daring, Guru hanya menyampaikan materi pemebelajaran saja kepada anak tanpa memperhatikan penumbuhan karakter anak. Anak yang memiliki dukungan dari keluarga akan menumbuhkan karakter yang baik, akan tetapi jika tidak ada dukungan dari orang tua, maka karakter religius anak akan menurun (Suriadi et al., 2021). 
3087 Kendala dalam Menumbuhkan Karakter Religius Anak Usia Sekolah Dasar Selama Pandemi Covid 19 Unsa Sabrina, Sekar Dwi Ardianti, Diana Ermawati

DOI: https://doi.org/10.31004/edukatif.v3i5.1233

\section{Pengaruh Lingkungan}

Lingkungan menjadi hal yang sangat berpengaruh terhadap proses penumbuhan karakter religius anak. Hal tersebut sejalan dengan hasil penelitian yang dilakukan kepada KI, yang menunjukkan bahwa setiap hari KI menghabiskan waktu bermain dengan teman-temannya hingga menjelang sore hari.

"Saya setiap hari dengan teman-teman saya hingga menjelang sore"

Hal tersebut sesuai dengan hasil observasi kepada KI yang menghabiskan waktu setiap harinya dengan bermain sehingga berdampak pada beberapa hal diantaranya KI melewatkan sholat dzuhur dan tidak berangkat TPQ karena mengikuti temannya yang tidak. Pengaruh lingkungan menjadi salah satu penghambat pertumbuhan karakter anak karena pada anak usia SD masih mudah terpengaruh dan meniru keadaan lingkungan. Saat berada di lingkungan luar rumah, anak memiliki teman dan ruang gerak yang berbeda ketika anak berada di rumah yang menyebabkan anak cenderung meniru sikap teman-temannya tanpa membedakan yang baik dan yang buruk (Widianto, 2015:36). Hal tersebut sesuai dengan hasil penelitian oleh Ahsanulkhaq (2019) yang mengatakan lingkungan sebagai tempat sosialisasi anak menjadi hal yang sangat berpengaruh terhadap baik buruknya perilaku anak. Jika anak berada pada lingkungan yang baik, maka akan membawa kebaikan. Sebaliknya jika lingkungan pada anak kurang baik maka akan menjadi kendala menumbuhkan karakter religius pada anak.berangkat.

\section{KESIMPULAN}

Berdasarkan penelitian yang peneliti lakukan di Desa Lau Kecamatan Dawe Kabupaten Kudus mengenai kendala dalam menumbuhkan karakter religius selama pandemi covid 19 menurun. Banyak kegiatan yang biasa dilakukan oleh anak di sekolah tidak dilakukan anak selama di rumah. Kendala menerapkan karakter religius anak adalah kurangnya pengetahuan orang tua, kurangnya kesadaran dalam diri anak, kesibukan orang tua, tidak adanya koordinasi orang tua dan guru serta pengaruh lingkungan.Orang tua seharusnya dapat memahami betapa pentingnya karakter religius untuk anak selama pandemi covid 19 karena peran orang tua sangat berpengaruh terhadap karakter anak. Orang tua dapat mengupayakan karakter anak dengan menasehati, memberikan tealdan dan memberikan hukuman. Dengan memaksimalkan 3 upaya tersebut, karakter anak akan tumbuh dengan baik. Selain orang tua, guru juga tetap mengupayakan agar anak melaksanakan kegiatan-kegiatan religius. Upaya yang dapat dilakukan guru diantaranya mendesain pembelajaran daring yang didalamnya bermuatan karakter religius, memotivasi siswa agar tetap semangat melaksanakan kegiatan-kegitan religius dan yang terpenting menjalin kerjasama dengan orang tua untuk memantau kegiatan-kegiatan anak yang berkaitan dengan karakter religius.

\section{DAFTAR PUSTAKA}

Abdusshomad, A. (2020). Pengaruh Covid-19 Terhadap Penerapan Pendidikan Karakter Dan Pendidikan Islam. QALAMUNA: Jurnal Pendidikan, Sosial, Dan Agama, 12(2). Https://Doi.Org/10.37680/Qalamuna.V12i2.407

Ahsanulkhaq, M. (2019). Membentuk Karakter Religius Peserta Didik Melalui Metode Pembiasaan. Jurnal Prakarsa Paedagogia, 2(1), 21-33.

Aisyah, S. (2019). Upaya Dalam Membentuk Karakter Religius Peserta Didik Di SD N Kompleks IKIP 1 Makassar. UIN Alauddin Makassar.

Al-Ulum, J. (2013). Kesadaran Diri Proses Pembentukan Karakter Islam Malikah Institut Agama Islam Negeri Sultan Amai Gorontalo. 129-150.

Alifah, N. (2020). Implementasi Pendidikan Karakter Religius Di Mi Ma'Arif Nu Windunegara Kecamatan Wangon Kabupaten Banyumas Program Studi Pendidikan Guru Madrasah Ibtidaiyah : Nur Alifah. 
3088 Kendala dalam Menumbuhkan Karakter Religius Anak Usia Sekolah Dasar Selama Pandemi Covid 19 Unsa Sabrina, Sekar Dwi Ardianti, Diana Ermawati

DOI: https://doi.org/10.31004/edukatif.v3i5.1233

Asyari, M. M., Ismaya, E. A., \& Ahsin, M. N. (2021). Nilai-Nilai Pendidikan Karakter Dalam Tradisi Apitan Masyarakat Singocandi Kudus. WASIS: Jurnal Ilmiah Pendidikan, 2(1), 34-40. Https://Doi.Org/10.24176/Wasis.V2i1.5764

Azzet, A. M. (2014). Urgensi Pendidikan Karakter Di Indonesia. Ar-Ruz Media.

Fatmala, S., Bintoro, H. S., \& Ardianti, S. D. (2021). Analisis Perhatian Orang Tua Selama Pembelajaran Daring Terhadap Kemampuan Pemahaman Matematis Siswa. Jurnal Ilmiah Bina Edukasi, 14(1), 01-10. Https://Doi.Org/10.33557/Jedukasi.V14i1.1365

Irhamna. (2019). Analisis Tentang Kendala-Kendala Yang Dihadapi Orang Tua Dalam Pembinaan Akhlak Dan Kedisiplinan Belajar Siswa Madrasah Darussalam Bengkulu. Al-Bahtsu, 1(1), 57-65. Https://Ejournal.Iainbengkulu.Ac.Id/Index.Php/Albahtsu/Article/View/355

Istifany, P. (2018). Penanaman Nilai-Nilai Karakter Religius Dan Karakter Kebangsaan Di Madrasah Tsanawiyah Al Falah Jatinangor Sumedang. Jurnal Pendidikan Karakter, 8(1), 84-94. Https://Doi.Org/10.21831/Jpk.V8i1.21677

Jannah, N., \& Suryadilaga, M. A. (2020). Mengajarkan Shalat Pada Anak Usia Dini Dalam Masa Social Distancing Covid-19 ᄀPerspektif Hadis. AL QUDS : Jurnal Studi Alquran Dan Hadis, 4(2), 427. Https://Doi.Org/10.29240/Alquds.V4i2.1638

Kemendikbud. (2017). Konsep Dan Pedoman Penguatan Pendidikan Karakter. Pusat Analisis Dan Sinkronisasi Kebijakan Sekretariat Jendral Kementrian Pendidikan Dan Kebudayan.

Kurniawan, S. (2016). Pendidikan Karakter: Konsepsi \& Implementasinya Secara Terpadu Di Lingkungan Keluarga, Sekolah, Perguruan Tinggi \& Masyarakat. Ar-Ruz Media.

Mahmudin, H., \& Muhid, A. (2020). Peran Orang Tua Mendidik Karakter Anak Dalam Islam. Jurnal Darussalam: Jurnal Pendidikan, Komunikasi Dan Pemikiran Hukum Islam, 11(2), 449. Https://Doi.Org/10.30739/Darussalam.V11i2.624

Muhsin, A. (2017). Upaya Orang Tua Dalam Membentuk Karakter Anak Di Dusun Sumbersuko Desa Plososari Kecamatan Grati Kabupaten Pasuruan. DINAMIKA: Jurnal Kajian Pendidikan Dan Keislaman, 2(02), 123-150. Https://Doi.Org/10.32764/Dinamika.V2i02.174

Prabowo, S. H., Fakhruddin, A., \& Rohman, M. (2020). Peran Orang Tua Dalam Pembentukan Karakter Anak Di Masa Pandemi Covid-19 Perspektif Pendidikan Islam Abstrak Kata Kunci : Peran Orang Tua , Pendidikan Karakter, Pandemi Covid-19, Pendahuluan Keberhasilan Pendidikan Formal Yang Ditempuh Seorang Anak Tida. Pendidikan Islam, 11(2), 191-207.

Rambe, H. (2018). Peran Orang Tua Dalam Membentuk Karakter Relegius Pada Anak Di Desa Tanjung Siram Kecamatan Bilah Hulu Kabupaten Labuhanbatu Tahun 2017 ( Studi Kasus : Dusun Siborangan ). Civitas (Jurnal Pembelajaran Dan Ilmu Civic), 2(1), 11-21. Https://Doi.Org/10.36987/Civitas.V2i1.1045

Rangga, K., Saputro, J., Ulya, H., \& Fardani, A. (2021). Pengaruh Perhatian Orang Tua Selama Pembelajaran Daring Terhadap Prestasi Belajar Siswa Sd 2 Karangrowo. X, 1-7.

Roesdiana, N. D. (2017). Analisis Pembentukan Karakter Religius Siswa Di Sdn 03 Suruh Tasikmadu Karanganyar Tahun Ajaran 2016/2017. Universitas Muhammadiyah Surakarta.

Rohman, Murtono, \& Su'ad. (2021). Penerapan Nilai-Nilai Karakter Sifat. 11(2).

Rositania, L. W., \& Ardianti, S. D. (2021). Disiplin Belajar Anak Selama Pembelajaran Daring Di Desa Trangkil $R w 02.2(1), 30-42$.

Roziqin, K., Martati, B., \& Putra, D. A. (2021). Analisis Karakter Religius Siswa Dalam Belajar Dari Rumah Pada Masa Pandemi Covid-19. Jurnal Kajian Pendidikan Dan Hasil Penelitian, 7(1), 1-6.

Setiardi, D. (2017). Keluarga Sebagai Sumber Pendidikan Karakter Bagi Anak. Tarbawi : Jurnal Pendidikan Islam, 14(2). Https://Doi.Org/10.34001/Tarbawi.V14i2.619 
3089 Kendala dalam Menumbuhkan Karakter Religius Anak Usia Sekolah Dasar Selama Pandemi Covid 19 Unsa Sabrina, Sekar Dwi Ardianti, Diana Ermawati

DOI: https://doi.org/10.31004/edukatif.v3i5.1233

Setiawan, A. (2021). Pendidikan Karakter Pada Peserta Didik Di Masa Pandemi Covid-19 Berbasis Keluarga. Jurnal Ilmiah Mandala Education, 319-327. Http://Ejournal.Mandalanursa.Org/Index.Php/JIME/Indexterakreditasiperingkat4

Shidiq, U., \& Choiri, M. (2019). Metode Penelitian Kualitatif Di Bidang Pendidikan. In Journal Of Chemical Information And Modeling (Vol. 53, Issue 9). Http://Repository.Iainponorogo.Ac.Id/484/1/METODE Penelitian Kualitatif Di Bidang Pendidikan.Pdf

Suriadi, H. J., Firman, F., \& Ahmad, R. (2021). Analisis Problema Pembelajaran Daring Terhadap Pendidikan Karakter Peserta Didik. Edukatif: Jurnal Ilmu Pendidikan, 3(1), 165-173. Https://Doi.Org/10.31004/Edukatif.V3i1.251

Trisnadewi, K., \& Muliani, N. M. (2020). Pembelajaran Daring Di Masa Pandemi Covid -19. In Kadek Aria Prima Dewi PF \& J. Simarmat (Eds.), Covid 19 Perspektif Pendidikan (1st Ed.). Yayasan Kita Menulis.

Utami, A. T. (2014). Pelaksanaan Nilai Religius Dalam Pendidikan Karakter Di SD Negeri 1 Kutowinangun Kebumen. Universitas Negeri Yogyakarta.

Widianto, E. (2015). Peran Orang Tua Dalam Meningkatkan Pendidikan Karakter Usia Dini Dalam Keluarga. Jurnal PG-Paud Trunojoyo, 2(1).

Yunitasari, R., \& Hanifah, U. (2020). Pengaruh Pembelajaran Daring Terhadap Minat Belajar Siswa Pada Masa COVID 19. Edukatif: Jurnal Ilmu Pendidikan, 2(3), 232-243. Https://Doi.Org/10.31004/Edukatif.V2i3.142

Zubaedi. (2011). Desain Pendidikan Karakter. Kencana Penada Media Group. 